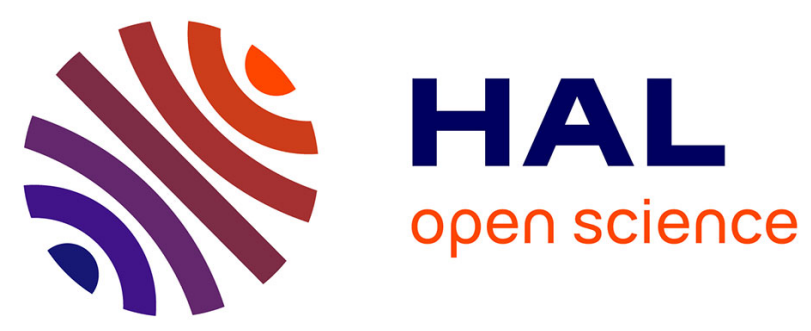

\title{
Experimental investigation of the equivalence ratio influence on combustion, performance and exhaust emissions of a dual fuel diesel engine operating on synthetic biogas fuel
}

F.Z. Aklouche, Khaled Loubar, A. Bentebbiche, Sary Awad, Mohand Tazerout

\section{- To cite this version:}

F.Z. Aklouche, Khaled Loubar, A. Bentebbiche, Sary Awad, Mohand Tazerout. Experimental investigation of the equivalence ratio influence on combustion, performance and exhaust emissions of a dual fuel diesel engine operating on synthetic biogas fuel. Energy Conversion and Management, 2017, 152, pp.291-299. 10.1016/j.enconman.2017.09.050 . hal-01731269

\author{
HAL Id: hal-01731269 \\ https://hal.science/hal-01731269
}

Submitted on 20 Nov 2018

HAL is a multi-disciplinary open access archive for the deposit and dissemination of scientific research documents, whether they are published or not. The documents may come from teaching and research institutions in France or abroad, or from public or private research centers.
L'archive ouverte pluridisciplinaire HAL, est destinée au dépôt et à la diffusion de documents scientifiques de niveau recherche, publiés ou non, émanant des établissements d'enseignement et de recherche français ou étrangers, des laboratoires publics ou privés. 


\title{
Experimental investigation of the equivalence ratio influence on combustion, performance and exhaust emissions of a dual fuel diesel engine operating on biogas fuel
}

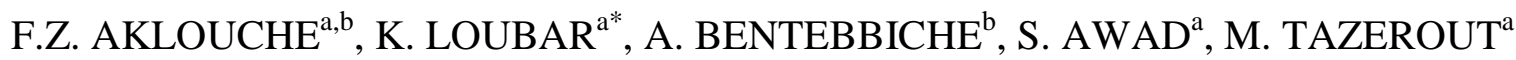 \\ ${ }^{a}$ GEPEA, UMR 6144, DSEE, Ecole des Mines de Nantes, Nantes 44307, France. \\ ${ }^{b}$ Mechanics and Energy Conversion Systems Laboratory, University of Sciences and \\ Technology HOUARI BOUMEDIENE, Algiers, ALGERIA.
}

\begin{abstract}
In this work, an experimental investigation was conducted to analyze dual fuel engine (DF) operation using biogas fuel under high load at constant percentage energy substitution rate (PES). The performance, the ignition delay and other combustion characteristics of engine operating in dual fuel mode (biogas/diesel) are compared to the conventional mode. The biogas, composed of $60 \%$ methane and $40 \%$ carbon dioxide, is the primary fuel which is blended with air in the engine inlet manifold, whereas the pilot fuel is diesel. The equivalence ratio $(\phi)$ was varied by changing air flow rate while the energy introduced into the engine remained constant for all the examined cases. Combustion analysis showed that with increasing $\phi$, the ignition delay tends to become longer and the peak of heat release rate was increased. Furthermore, as the $\phi$ increased from 0.35 to 0.7 , THC and $\mathrm{CO}$ emissions were reduced by $77 \%$ and $58 \%$ respectively. The NOx emissions decreased at $60 \%$ PES by $24 \%$ while the BTE was improved by $13 \%$.
\end{abstract}

Keywords: Biogas; dual fuel engine; combustion; pollutant emissions; equivalence ratio.

\footnotetext{
*Corresponding author. Tel.: (+33) 0251858282.

E-mail address: Khaled.Loubar@mines-nantes.fr (K. Loubar).
} 


\section{Introduction}

The development of internal combustion engines and the process of reducing pollutant produced by fuel combustion have become mandatory requirements for propulsion systems designers. One of the main objectives is to find the best way to minimize the emissions without considerably modify the engine's mechanical structure while maintaining the same performance. One of the proposed solutions is the method of injection of diesel fuel and the use of diverse gaseous fuels like biogas, natural gas, etc.

As a result of the gradual depletion of fossil oil and the environmental degradation, the utilization of gaseous fuel from biomass attracts the attention of the researchers. Thus, the use of some alternative gaseous fuels in the diesel engine increases worldwide. Biogas is an alternative fuel produced through a biological process. In the absence of oxygen (anaerobic condition), the methanization reaction starts spontaneously when organic matter is in a tepid environment, where it decomposes to form a gas mixture called biogas. Raw materials like industrialized waste, agricultural and biomass present an important potential for the generation of biogas but are underutilized [1-3]. However, the biogas composition varies according to parameters such as humidity, gas pockets and variations of the waste location [4].

Because of the increasing demand to reduce the pollutant emissions of existing technologies of internal combustion engine (ICE), several researches have been carried out investigating new approaches to achieve this goal. However, amongst several studies which were realized, the conversion of the diesel engine into a dual fuel (DF) engine, so as to use the alternative fuel, showed interesting results. In this mode, gaseous fuel is injected into the inlet manifold where it is mixed with air. After that, the gaseous mixture is entered into the combustion chamber where the pilot fuel, which has an important cetane number, is directly injected, and then ignites to initiate the combustion [6,7]. It is noted that biogas is a recommended fuel for 
engines which have a big compression ratio taking advantage of its important octane number allowing higher thermal efficiency. It was also reported that with minor modifications of the diesel engine, the biogas could be used [8]. In fact, a compression ignition engine running in conventional mode can be just altered into DF mode by branching a gas blender to its intake manifold. Moreover, a fuel test system must be placed to adjust the flow rate of the injected diesel fuel [9]. Also, it was suggested that the engine operating in DF mode running in biogas can be used to reduce the quantity of the diesel injected and at the same time diminish the compromise between NOx and smoke [9-13].

In diesel engines, nearest the injection of the diesel, the air temperature is around $553 \mathrm{~K}$. However, in dual fuel mode, under these conditions, the biogas cannot ignite without the presence of a little quantity of pilot fuel to raise the temperature up to a temperature of about 1087K [14]. Furthermore, it has also been observed that, the dual fuel engine requires an extended combustion duration and at the same time an over long ignition delay [15-17]. In addition, it was noticed that the ignition delay can be shortened with the use of a fuel possessing a great stage of dissolved oxygen, and a high cetane number. Also, a reduction of the emission of exhaust can be observed [18].

Various gaseous fuels (methane, propane, CNG, LPG, hydrogen) can be used to power the diesel engine operating in DF mode while maintaining engine efficiency, and reducing exhaust emissions $[19,20]$. Furthermore, the reduction of some exhausts emissions and the improvement of the engine efficiency can be achieved by the optimizing of certain parameters influencing the engine, such as, substitution ratio, injection timing, engine loads [21], and inlet air temperature [22]. Moreover, it was noticed by Makareviciene et al. [23] that the combustion performance was better with variation of injection timing.

Srinivasan et al [24] found that DF (natural gas/diesel) engine could participate to minimize carbon dioxide emission by reason of the smallest carbon-hydrogen ratio. The natural gas may 
decrease greatly both NOx emission and soot $[25,26]$, which is complicated to attain in conventional mode. In addition, for various advantages of natural gas, it may be used like an additional fuel to operating in DF mode [26]. That is why former studies showed that the use of the biomethane as a fuel for vehicles is preferable for the energy production [27].

Additionally, dual fuel mode using biodiesel as pilot fuels [28-31] shows a lowering of particulate emissions with the increasing of load [30]. This was explained by the important combustion temperature and enabling combustion amelioration. Luijten and Kerkhof [32] have replaced the diesel by the Jatropha oil to ignite the DF engine operating with biogas. A reduction of about $10 \%$ of the brake thermal efficiency was observed. Similar observation was reported by other researchers using different pilot fuels (karanja methyl) [33]. Papagiannakis et al [34] obtained the effects of the amount of natural gas on NOx emissions. The results showed that the augmentation of natural gas mass ratio has a good effect to minimize NOx emissions.

On the other hand, the effect of the biogas composition in DF mode was studied by Daouk et al [35]. They noted that the biogas containing $70 \%$ methane (by volume) and about 30\% carbon dioxide has advantages in terms of emissions compared to the conventional mode. Also, the study of the performance of dual fuel (biogas-diesel) was established by Lounici et al [20], where a good knock resistance was observed from measured torque at the knock onset.

It was reported by several researchers that the high levels of THC emissions produced by DF combustion is considered as a disadvantage of this mode. In fact, it was achieved in other works that the hydrocarbon emission in normal diesel mode was lower than that in dual fuel operation, with about $6000 \mathrm{ppm}[36,37]$. In spite of the fact that, in DF mode, the THC emissions were decreased as engine load increases, but the value of hydrocarbon emission 
was even more important by about 2000 ppm [38] and 2.5 times [39] in DF mode with natural gas. Thus, the need to get a method to diminish the THC emissions on a DF mode emerges. Various methods were used in DF engine (NG/diesel) to reduce the THC without lowering the thermal efficiency, such as using injection timing [40], gas recirculation burning [41], raising the quantity of pilot fuel [42], etc.

Previous studies focused mainly on the use of natural gas for engines running in DF mode with respect to biogas. There are fewer studies about the biogas as a high potential alternative source of energy for compression ignition engines. Moreover, these studies stated that the use of biogas can be limited by the high levels of pollutant emissions, especially unburned hydrocarbon. Thus, the main objective of the present study is to investigate the use of biogas in CI engine and to propose a technique to reduce the pollutant emissions without any drawbacks on the performance of engine at high load. The proposed technique is based on varying the total equivalence ratio using a throttle valve to adjust the air mass flow rate.

\section{Materials and procedure}

\subsection{Biogas used in engine test}

In general, the composition of biogas fuel is ranging from $50 \%$ to $70 \%$ (by volume) for methane and $30 \%$ to $50 \%$ for carbon dioxide. In this study, $\mathrm{CH}_{4}$ and $\mathrm{CO}_{2}$, stored separately in pressurized bottles, were used in the engine test with a percentage of $60 \%$ and $40 \%$ respectively. The biogas used was prepared using a computer controlled mixer.

In the beginning, the engine is operated only on diesel fuel to prepare the engine (warm up and stabilize). After that, the engine is switched to dual fuel mode. The synthesized gaseous fuel passes through a line to the intake manifold after mixing. Close to the compression process ending, the flow rate of the pilot fuel injected into the combustion chamber is maintained constant to cover ten percent of the power output. After that, by increasing only 
the gaseous fuel flow (biogas), the power output is more rises. The compositions of primary

127 fuel and diesel fuel used for this study are shown in table 1.

128

129

\section{Table 1}

Diesel fuel and biogas properties.

\begin{tabular}{llc}
\hline Component & Primary fuel (Biogas) & Pilot fuel (diesel) \\
\hline Chemical Composition & $\begin{array}{l}60 \% \mathrm{CH}_{4}, 40 \% \mathrm{CO}_{2} \\
(\mathrm{~V} / \mathrm{V}(\%))\end{array}$ & $\mathrm{C}_{12} \mathrm{H}_{26}$ \\
\hline Cetane number & - & 49 \\
\hline Density $\left(\mathrm{kg} / \mathrm{m}^{3}\right)$ & 1.33 & 840 \\
\hline Stoichiometric air fuel ratio & 6.04 & 14.60 \\
\hline LHV $(\mathrm{MJ} / \mathrm{kg})$ & 17.65 & 42 \\
\hline
\end{tabular}

\subsection{Engine test and procedure}

In this study, the engine tests were carried out in the laboratory of Energy of Ecole des Mines scheme.

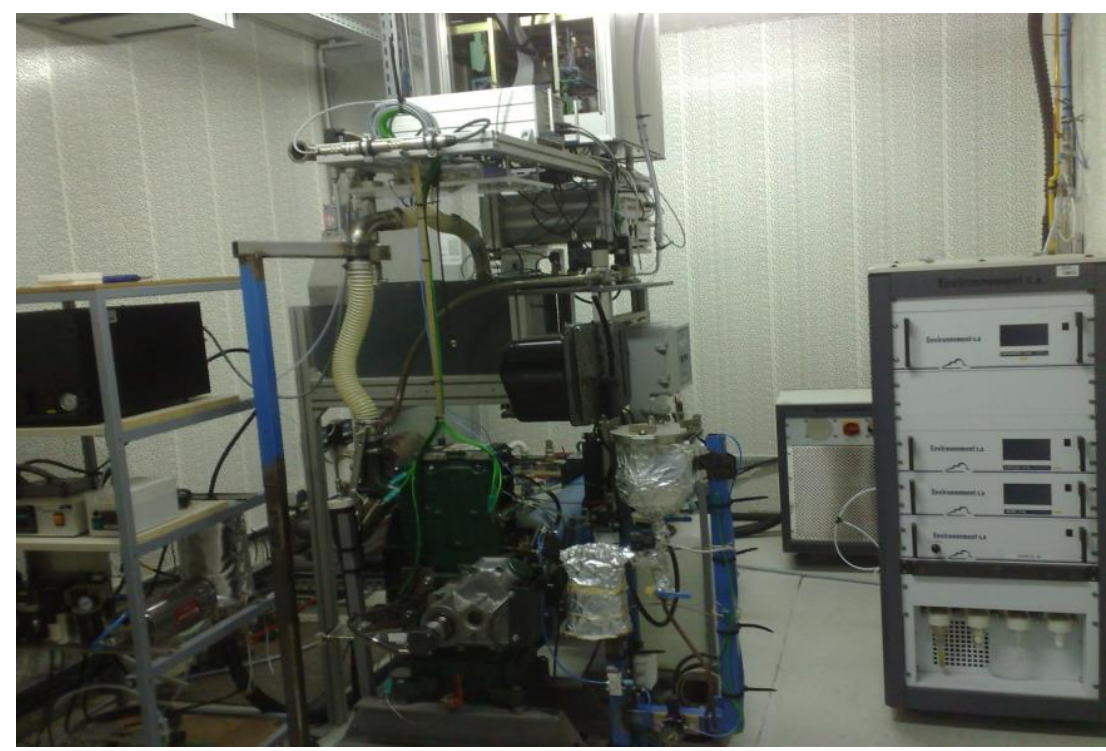

Fig.1. Experimental setup scheme. 
Using AVL software, the data was registered and analyzed from 100 cycles. A sampling interval of 0.2 crank angle (CA) is considered to obtain the combustion parameters. More details about the acquisition system; sensors precision and uncertainty calculation could be found in our previous works $[25,30]$.

Through the tests, the energy input under dual fuel operation (diesel pilot fuel+biogas) was

147 kept constant; this energy is allows to produce about $80 \%$ of the full load under conventional mode. The percentage energy substitution rate (PES) of biogas was kept constant $(60 \%)$ for 149 the different total equivalence ratios studied. The total equivalence ratio and the biogas percentage energy substitution rate are determined as following:

$\phi=\left(\dot{m}_{B} A F R_{B-t h}+\dot{m}_{D} A F R_{D-t h}\right) /\left(\dot{m}_{\text {air }}\right)$

Where $\dot{m}_{B}, \dot{m}_{D}$ and $\dot{m}_{\text {air }}(\mathrm{kg} / \mathrm{h})$ are the mass flow rates of biogas, diesel and air respectively. $A F R_{B-t h}$ and $A F R_{D-t h}(\mathrm{MJ} / \mathrm{kg})$ are the theoretical air fuel ratios of biogas and diesel respectively. $L H V_{B}$ and $L H V_{D}$ are the lower heating values of biogas and diesel respectively.

The injection timing of diesel fuel is fixed at $13^{\circ} \mathrm{CA}$ before top dead center (TDC). During dual fuel operation, $\phi$ was varied by adjusting the air flow rate using a throttle valve. However, for conventional diesel mode, the engine tests were conducted under wide open throttle (WOT) condition.

The calibration of the engine test bench was done according to the instructions given in the manufacturer catalog. The brake torque is measured from the dynamometer control system for a given operating condition. Parameters, such as the pressure cylinder, the flow rates of diesel, biogas and air are registered to analyze the engine efficiency. 


\section{Analysis combustion model}

168 In order to examine the combustion process in both modes, the heat release rate (HRR) must 169 be determined. The HRR can supply valuable information for understanding the engine

170

173

$\frac{d Q_{n e t}}{d \theta}=\frac{d Q_{c}}{d \theta}-\frac{d Q_{W}}{d \theta}=\frac{\gamma}{\gamma-1} P\left[\frac{d V}{d \theta}\right]+\frac{1}{\gamma-1} V\left[\frac{d P}{d \theta}\right]$

174 Where $\frac{d Q_{n e t}}{d \theta}$ is the net HRR, $\frac{d Q_{C}}{d \theta}$ is the rate of heat released by the fuel combustion and $175 \frac{d Q_{W}}{d \theta}$ is the heat transfer rate through the cylinder wall obtained from the Woschni's 176 correlation [43].

177

178 operating. It is calculated analytically by applying and the first law of thermodynamics and the law of ideal gas. Using the variation of the cylinder volume and the recorded value of the cylinder pressure, the following expression is used to obtain the HRR [43].

$$
\text { conrelation [43]. }
$$

$P$ is the cylinder pressure. $\gamma$ is the ratio of specific heats. $V$ represents the combustion chamber volume; it depends on the crank angle $(\theta)$ and the geometric parameters of the engine. The cylinder volume $V$ is obtained by the following equation:

$V(\theta)=V_{d}\left[\frac{C r}{C r-1}-\frac{1-\cos \theta}{2}+\frac{1}{2} \sqrt{\left(2 \frac{L}{C}\right)^{2}-\sin ^{2} \theta}\right]$

where $V_{d}, C_{r}, L$ and $C$ are respectively the displacement volume, the compression ratio, the connecting rod length and the stroke.

\section{Results and discussion}

\subsection{Combustion characteristics}

The results shown below are discussed for a percentage energy substitution rate (PES) of $60 \%$. The effect of the variation of total equivalence ratio was studied for the engine dual fuel 
(biogas/diesel) at high load. To diagnose combustion behavior, it is important to analyze the cylinder pressure history, which is obtained by the cylinder pressure data. The cylinder pressure data is used to plot the curves of cylinder pressure and the evolution of heat release rate (HRR), for the different total equivalence ratios with respect to crank angle. The incylinder pressure, ignition delay and net HRR for the conventional diesel and dual fuel (DF) operating modes at a constant engine speed of $1500 \mathrm{rpm}$ are shown below for $80 \%$ of load. A comparison was done between the results of the conventional and DF engine mode.

\subsubsection{Cylinder pressure}

Fig.2 shows the evolution of the cylinder pressure versus crank angle at various total equivalence ratios. As shown in fig.2, the highest peak of cylinder pressure, of 86 bars, is noticed for the conventional diesel mode, which occurs 5.4 after TDC. However, as the total equivalence ratio increases, the evolution, as well as the peak, of cylinder pressure of dual fuel operation decreases. A minimum peak of cylinder pressure of 63 bars is observed at $\phi=0.7$; it represents a reduction of about $26 \%$ in comparison to conventionel mode. In addition, it can be shown that the evolution of cylinder pressure also decreases even during the compression stage. Indeed, the reduction of the intake air flow, reduces the volumetric efficiency which reduces the in cylinder pressure. 


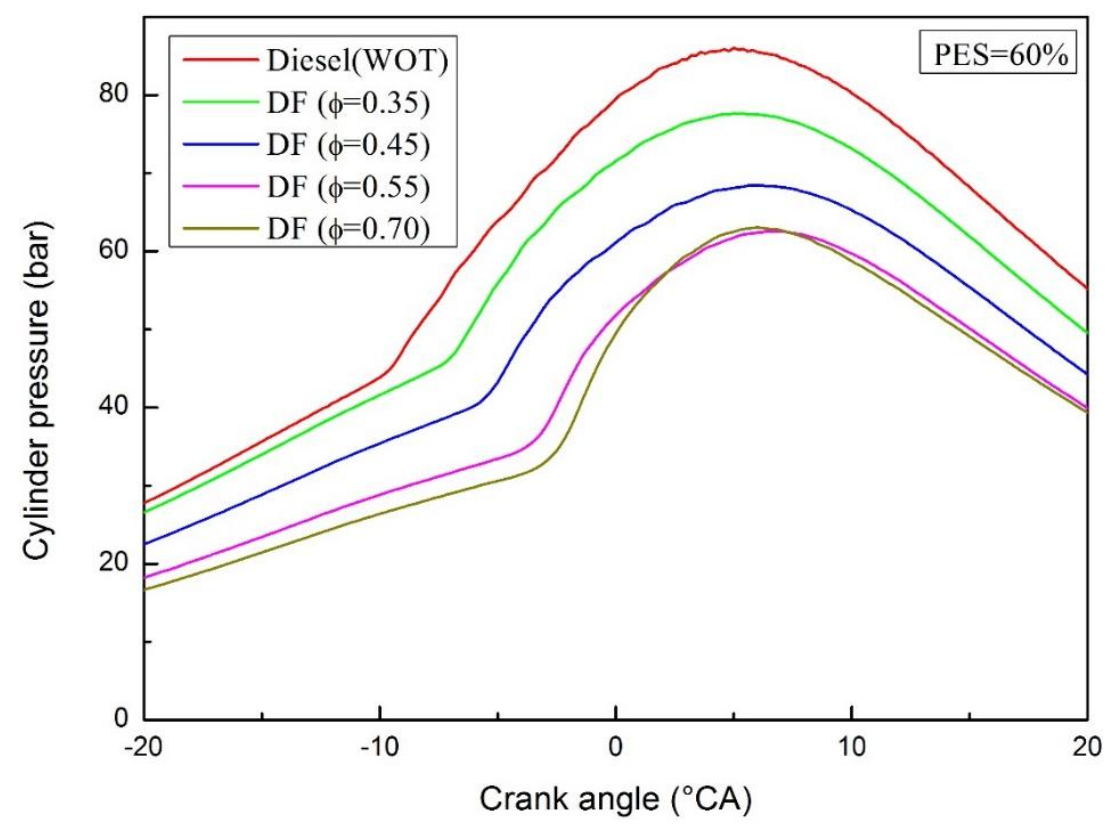
ratios $(\phi)$.

\subsubsection{Ignition delay}

The ignition delay (ID) can be defined as the crank angle (CA) interval between two points. The first point is the start of injection, and the second is the beginning of combustion. The combustion of biogas in DF mode undertakes a much complex process compared to that of diesel. Fig. 3 shows the plot of the ID evolution versus $\phi$ for DF mode (PES 60\%) compared to conventional mode. It can be seen that the ID of DF is greater than the conventional mode for all studied cases. In addition, the ID increases as $\phi$ increases. The value of the ignition delay varies between 3.8 and 7.6 for $\phi$ ranging from 0.35 to 0.7 . The reasons of the prolongation of ID are the reduction in the oxygen concentration, as the $\phi$ increases, and the diminution of the charge temperature [43] due to lower pressure as discussed previously (fig.2). On the other hand, this extension can also be caused by the specific heat capacity of biogas which is high. Furthermore, as reported by Wei Lijiang et al [44], the addition of biogas into the cylinder can delay the auto-ignition of pilot fuel because of the coupling between free radicals. In fact, the gaseous mixture (air/biogas) goes through a pre-ignition reaction over the compression phase. 
This chemical reaction affects the ignition of the pilot fuel, due to the formation of energetic radicals. Hence, the prolongation of ID can also be referred to chemical factors.

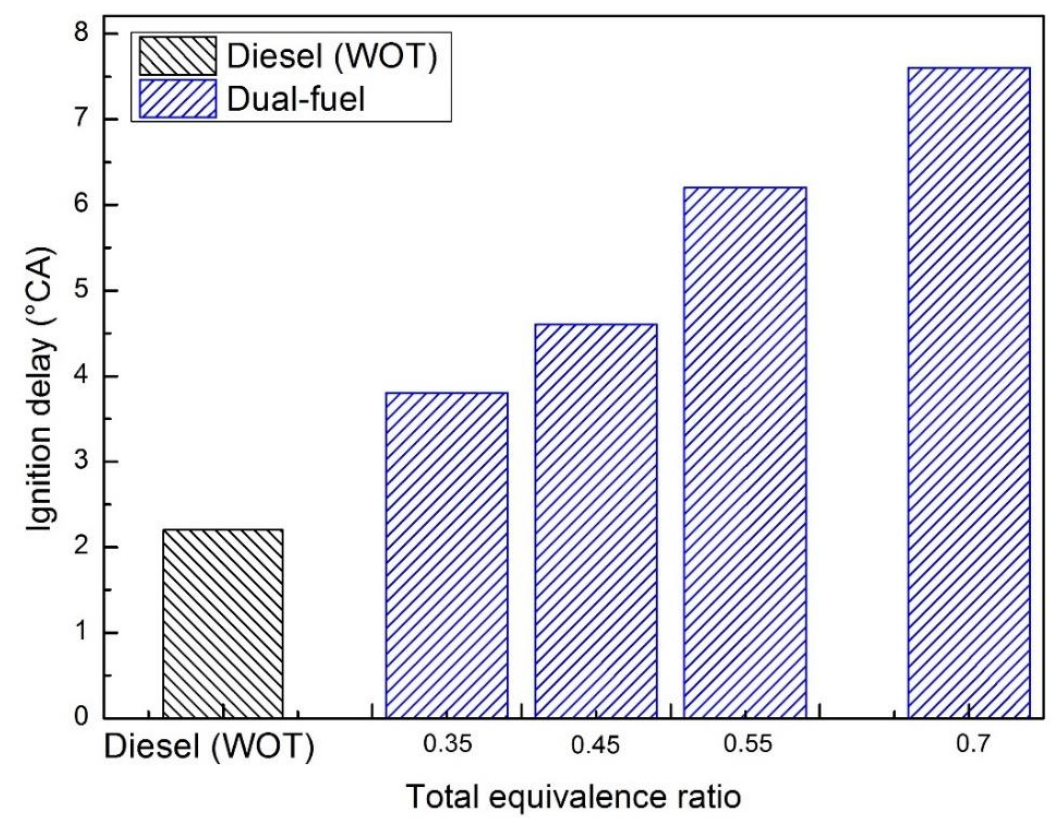

Fig.3. Ignition delay variation with $\phi$.

\subsubsection{Heat release}

Fig. 4 shows the evolution of the heat release rate (HRR) versus the crank angle (CA) for conventional and dual-fuel (DF) modes at different total equivalence ratios. As shown in fig. 3 , the combustion process, is divided into three phases namely: ignition delay, premixed phase (rapid combustion), and the diffusion combustion. At the beginning, one can visualize a negative heat release over the first phase which is explained by the vaporization of diesel fuel accumulated. As the combustion starts, the HRR takes positive value and increases until the peak of the second phase. This is followed by the diffusion combustion which is controlled by the (fuel- air) gaseous mixture. From fig.4, the peak of HRR increases with the increasing of $\phi$. Furthermore, the DF combustion start later with a few degrees of CA compared to the conventional mode due to the extension of ID as explained previously. The maximum and the minimum values of premixed peak of HRR for DF mode are $70 \mathrm{~J} / \mathrm{deg} \mathrm{CA}$ and $43 \mathrm{~J} / \mathrm{deg} \mathrm{CA}$ 
$243 \mathrm{~J} / \mathrm{deg} \mathrm{CA}$ is recorded in the case of conventional mode, which takes place at $8.8^{\circ} \mathrm{CA}$ before

244 TDC. Furthermore, at $0.35,0.45,0.55 \phi$, the diffusion combustion of DF mode is similar to

245 that in conventional mode. This can be interpreted by the augmentation of $\phi$ of the gaseous

246 mixture, owing to the rise of combustion temperature. Also, as $\phi$ increases the combustion

247 process enhances and the second phase is reinforced as result of the good mixture

248 concentration (fig.5), which gives a highest flame speed of gaseous mixture (biogas/air).

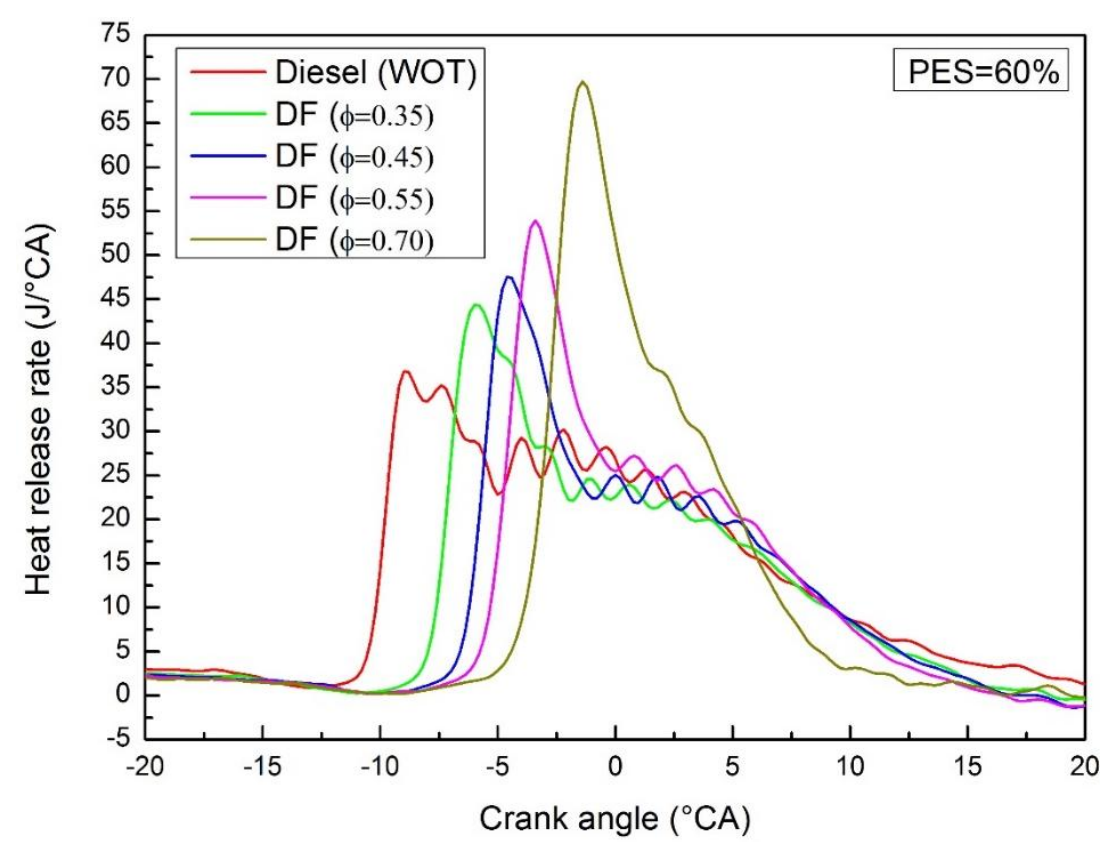

Fig.4. Heat release rate (HRR) with crank angle for different $\phi$. 


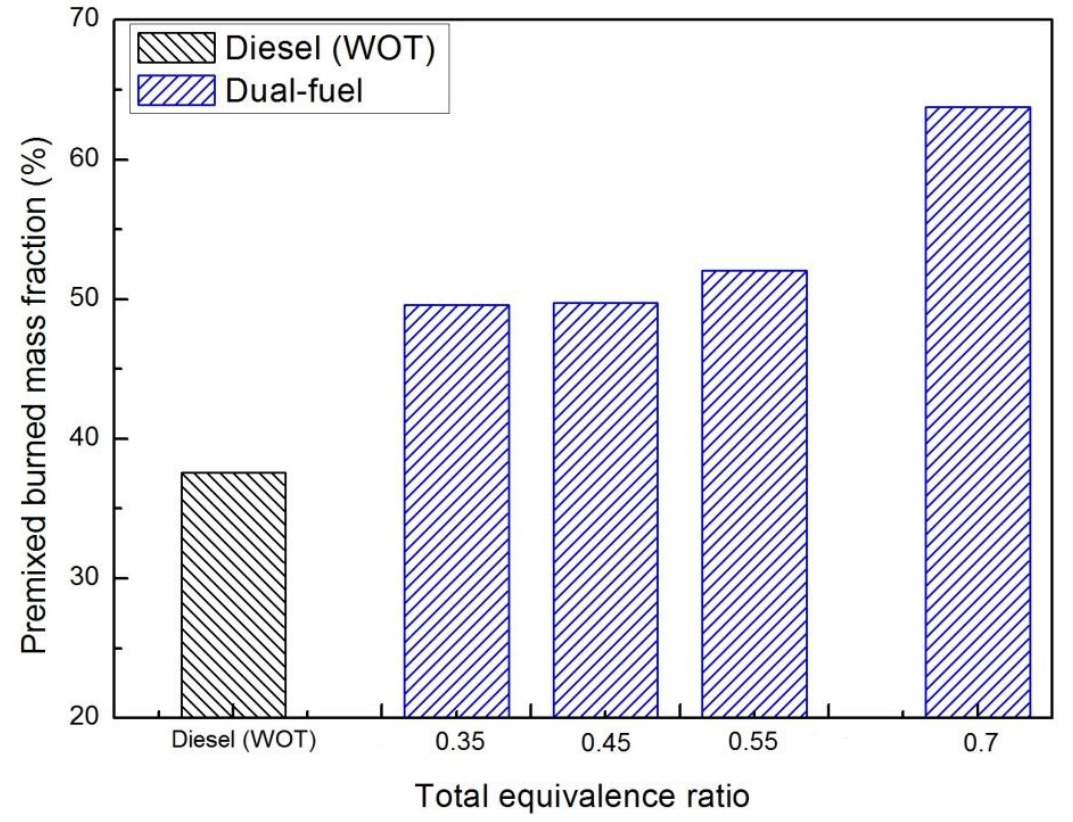

Fig.5. Evolution of the premixed burned mass fraction versus $\phi$.

\subsubsection{Combustion duration}

256 Fig.6 presents the evolution of the combustion duration with respect to total equivalence ratio. The combustion duration is presented in terms of crank angle. It is defined as the

258 duration between the instance where the HRR takes positive value and the instance at which $90 \%$ of the net heat is released [43]. The combustion duration decreases as $\phi$ rises. It varies

260 from 20.5 to $12.2 \mathrm{CA}$ when $\phi$ varies from 0.35 to 0.7 respectively. As known, at high $\phi$ the

261 burning velocity of biogas is higher than that at low $\phi[43]$, which consequently reducing the combustion duration, the same observation was achieved by Debabrata Barik et al [45]. 


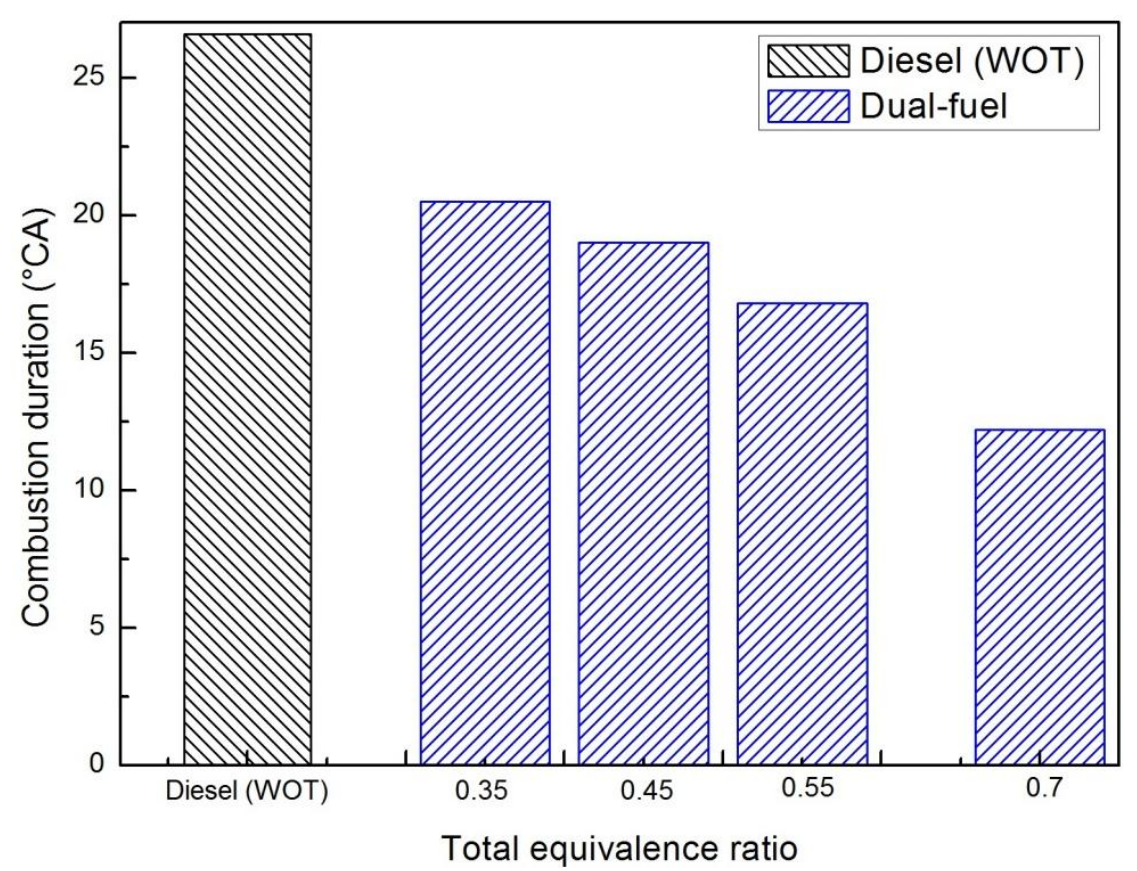

Fig.6. Variation of combustion duration versus $\phi$.

\subsection{Engine performance}

The evolution of the brake thermal efficiency (BTE) for DF operation and conventional diesel engine with $\phi$ are shown in fig.7. It can be calculated by the following expression:

$$
\eta_{\text {eff }}=P_{\text {eff }} /\left(\dot{m}_{B} L H V_{B}+\dot{m}_{D} L H V_{D}\right)
$$

Where $P_{\text {eff }}(\mathrm{kW})$ is the brake power. The BTE in dual fuel (DF) mode increases with increasing equivalence ratio (fig.7). Else, the BTE for the DF mode is higher than that of conventional mode for all the cases studied. For instance, the BTE of the engine operating in DF at $\phi=0.7$ is better than that of diesel mode by about $19 \%$. Indeed, as known, at high load, the BTE is improved when more biogas is provided to the cylinder. Regarding DF mode, the BTE increases with about $13 \%$ as $\phi$ increases. In fact, at high $\phi$ gaseous mixture (biogas/air) became more homogeneous. This is beneficial factor to have a complete combustion and limits misfires cases, which reduce THC emissions as it is shown in the next section and improve the BTE. 


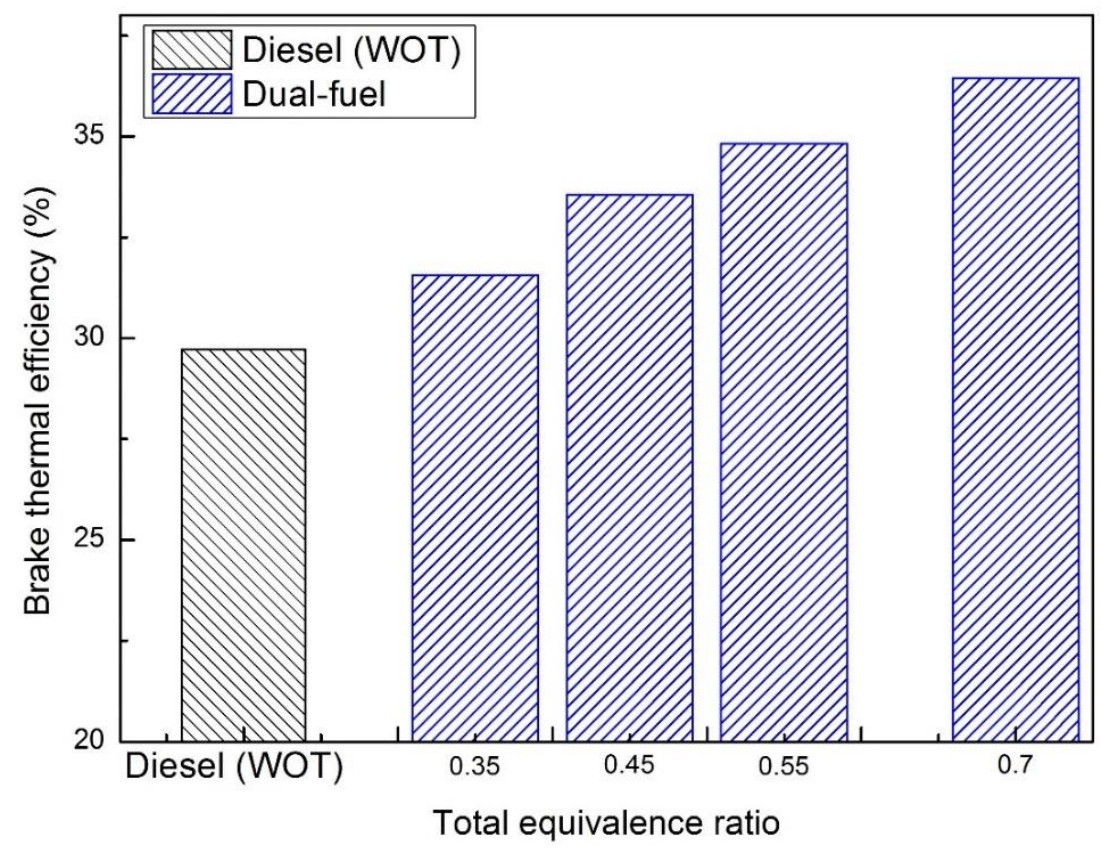

Fig.7. Evolution of the BTE with $\phi$.

284 The evolution of the brake specific consumption (BSFC) for both modes is depicted in fig.8.

285 It can be observed that the BSFC in DF mode takes much important values than that recorded

286 for conventional mode. This result is explained by the lower energy content of biogas fuel. On

287 the other hand, one can notice a reduction of BSFC as the $\phi$ increases from 0.35 to 0.7 for DF

288 mode. This can be assigned to the amelioration of combustion efficiency, leading to better

289 BTE and consequently reducing BSFC. 


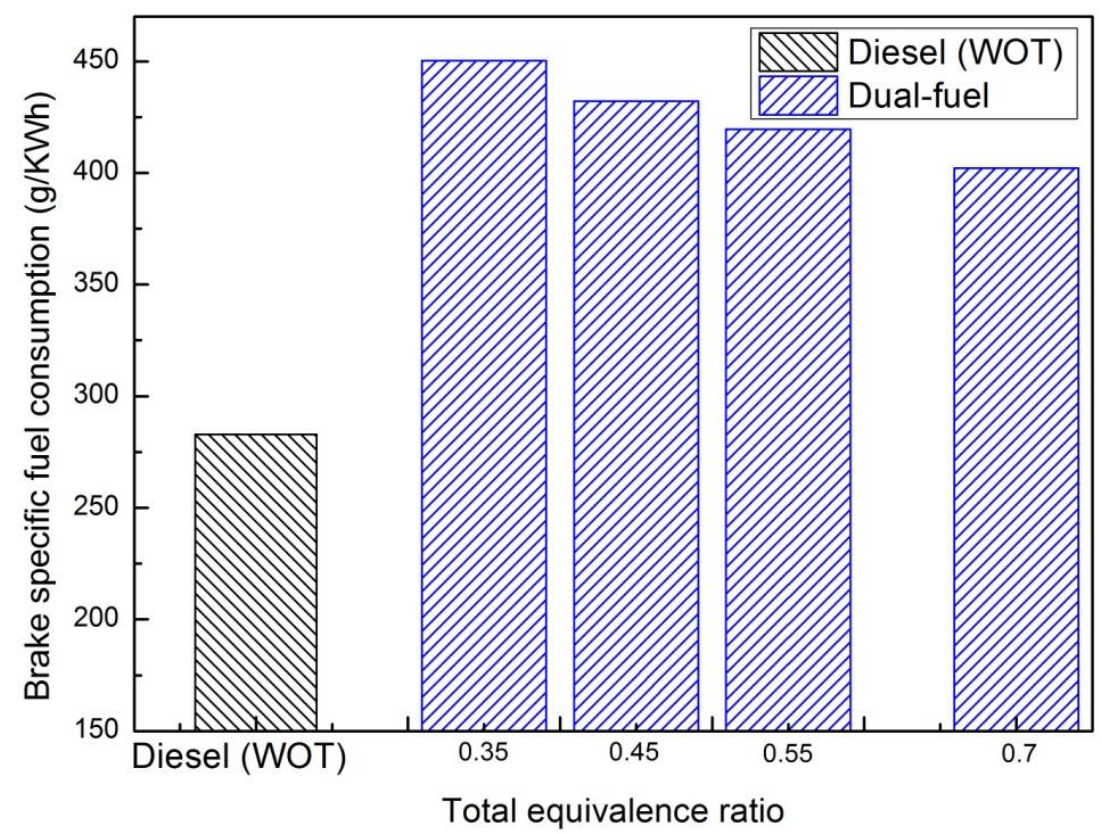

291

292

293

294

295

Fig.8. Evolution of the BSFC with $\phi$.

\subsection{Exhaust emissions}

In this part, the evolution of pollutant emissions was analyzed for different $\phi$ at $60 \%$ PES. In DF mode, the concentration of soot in the exhaust gas is very low at high load; a similar observation was reported by Lyes Tarabet et al [30]. Therefore, the evolution of soot is not presented in this study.

The variation of total unburned hydrocarbon (THC) related to the variation of $\phi$ is plotted in fig.9. As shown in fig.9, the concentration of THC emissions under DF mode is much important than that in conventional mode. On the other hand, it can be observed that THC emissions in DF mode decrease significantly with the augmentation of $\phi$. Indeed, changing $\phi$ from 0.35 to 0.7 results in a THC emissions decrease of about $77 \%$. This reduction can be particularly explained by the decrease of dilution of air/biogas mixture, which provides a good condition of fast flame propagation of biogas-air mixture. On the other hand, as stated previously the rich mixture leads to a better combustion process due to higher temperatures in the combustion chamber and limits misfires cases. 


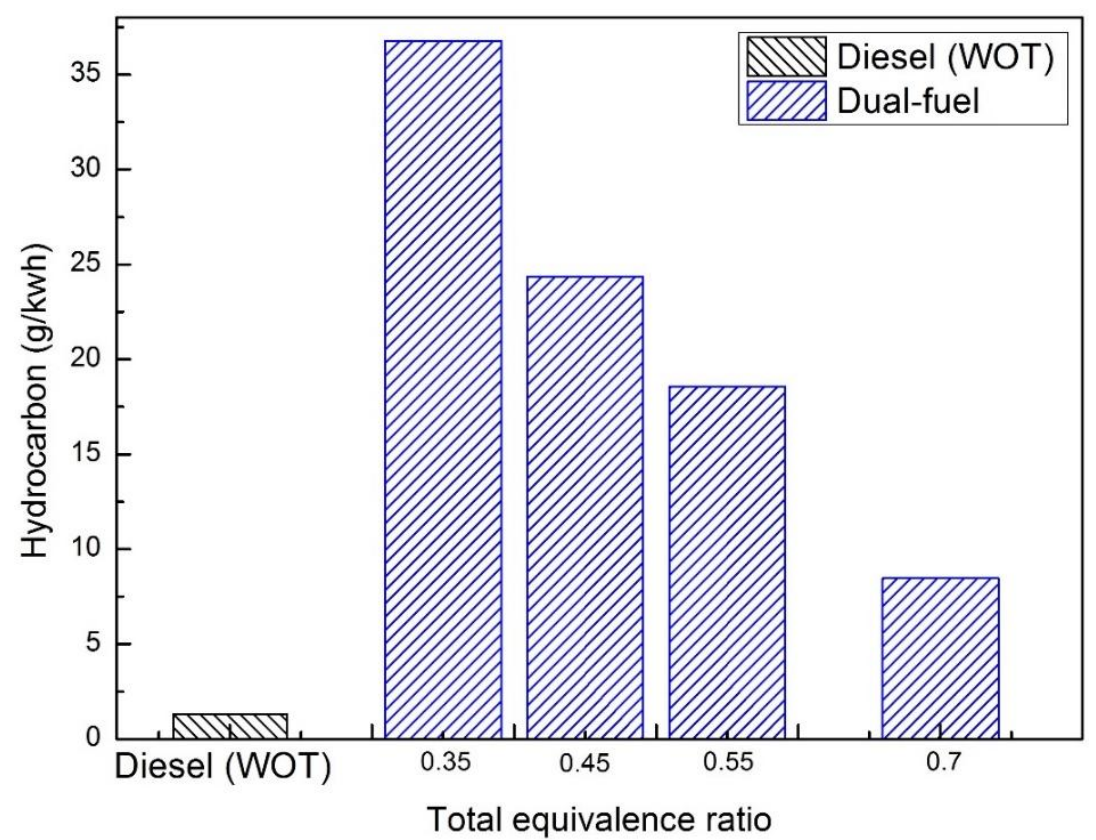

Fig.9. Variation of THC emissions versus $\phi$.

312 Fig.10 indicates the evolution of NOx emissions versus $\phi$. From this figure, a decrease of $24 \%$

313 of the NOx emissions was observed for DF mode with the rising of $\phi$. The conditions for 314 formation of NOx emissions according to zeldovich mechanism can be summarized in three terms: high peak flame temperature, $\mathrm{O}_{2}$-rich and the time of burned gas during the highest temperature. However, NOx emissions are essentially constituted by two gases, oxygen and

317 nitrogen. The absence of one of these components has a negative effect for the NOx 318 formation. Indeed, the introduction of biogas in the cylinder and the lowering of the intake air reduce the concentration of oxygen present in the cylinder, and consequently affect the NOx emission formation. On the other hand, a comparison with conventional mode shows that a reduction of NOx emissions of about $42 \%$ was achieved when $\phi=0.7$. 


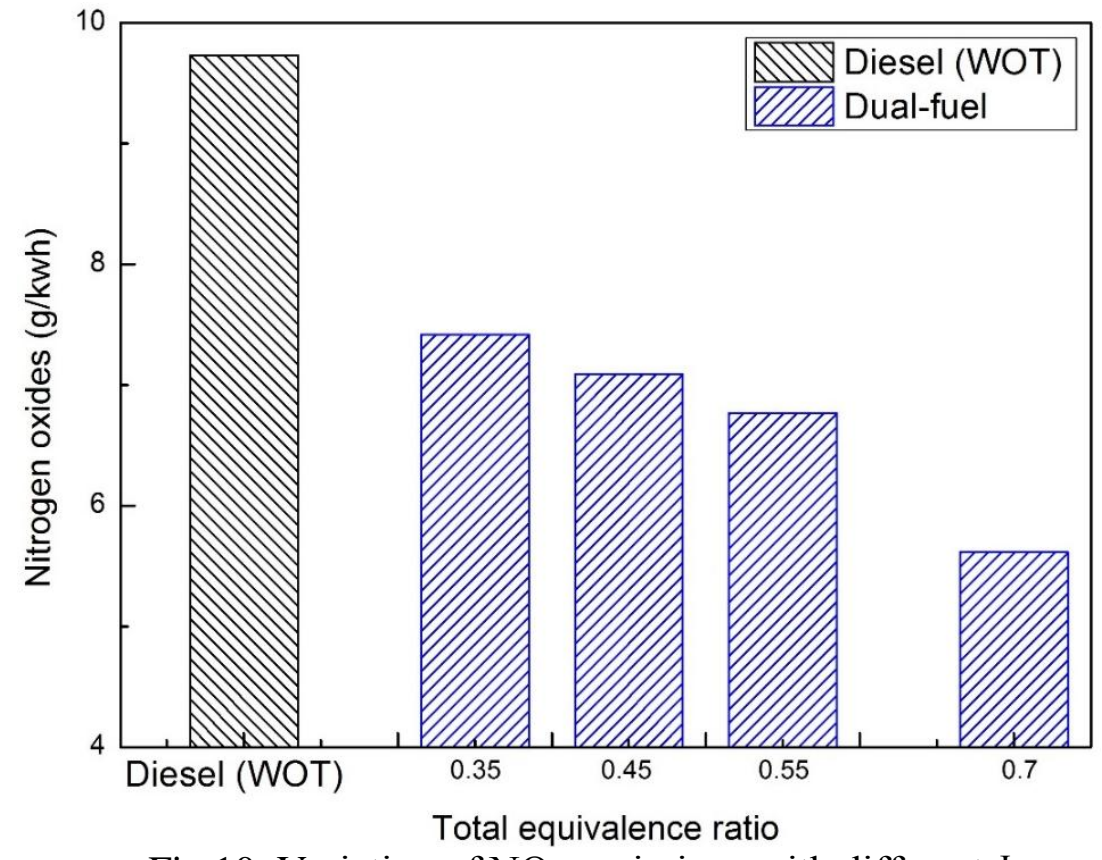

Fig.10. Variation of NOx emissions with different $\phi$.

326 Fig.11 shows the evolution of the carbon monoxide emissions (CO) with $\phi$. It may be noticed

327 that as the $\phi$ increases the concentration of the $\mathrm{CO}$ emissions decreases about $58 \%$. This is

328 again the result of the better flame propagation leading to a more complete combustion due to

329 the rich mixture. However, it can be also observed that, although the concentration of $\mathrm{CO}$

330 emission decreases with increasing $\phi$, the concentration of these pollutants is still twice that of

331 the conventional mode. 


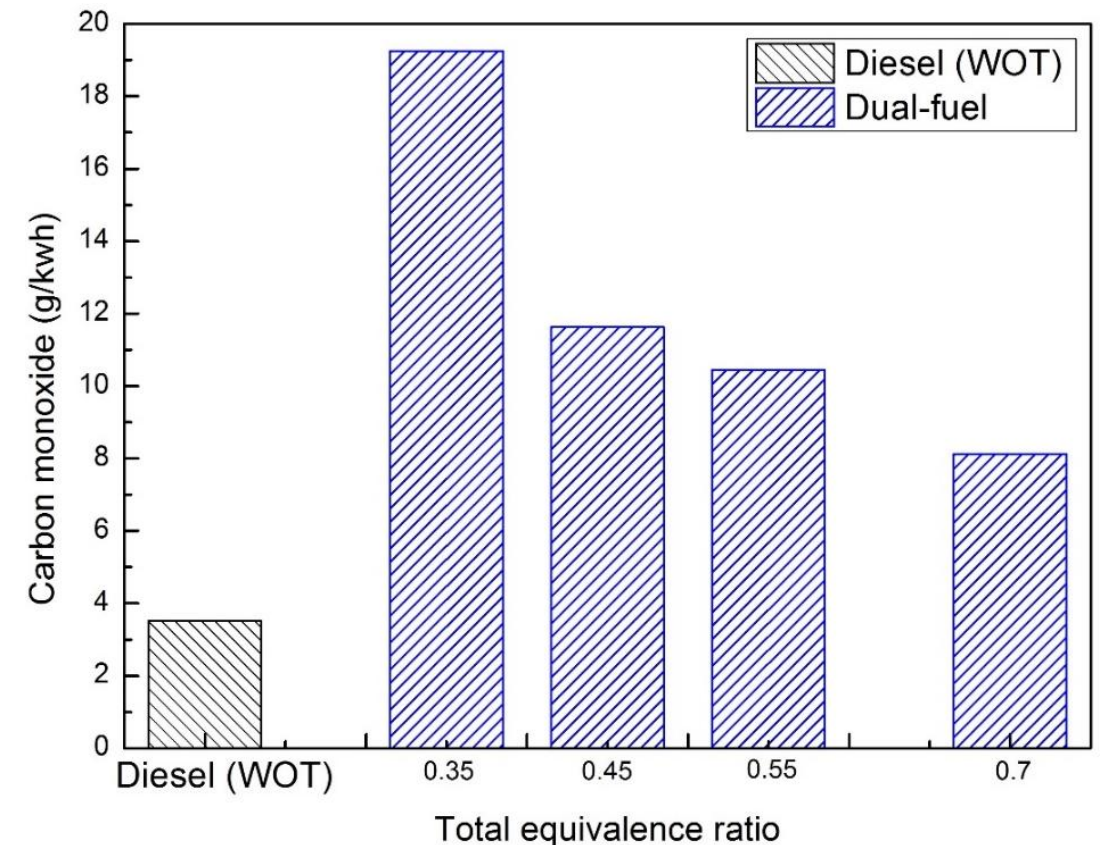

Fig.11. Evolution of $\mathrm{CO}$ emissions with various $\phi$.

336 Fig.12 shows the evolution of the carbon dioxide with increasing $\phi$. It can be observed that at

337 high $\phi$, the difference between the concentrations of $\mathrm{CO}_{2}$ for both modes is about $7 \%$. The 338 specific emission of $\mathrm{CO}_{2}(\mathrm{~g} / \mathrm{kWh})$ decreases about $14 \%$ with the augmentation of $\phi$ in the case 339 of DF mode. Indeed, as discussed previously, the increase of $\phi$ induces an improvement of 340 combustion process resulting in higher $\mathrm{CO}_{2}$ concentrations (\%Vol.) in the exhaust gas. 341 However, in the same time, the power output increases since the BET is becoming higher and 342 thus resulting in lower specific emission $(\mathrm{g} / \mathrm{kWh})$ when increasing $\phi$. 


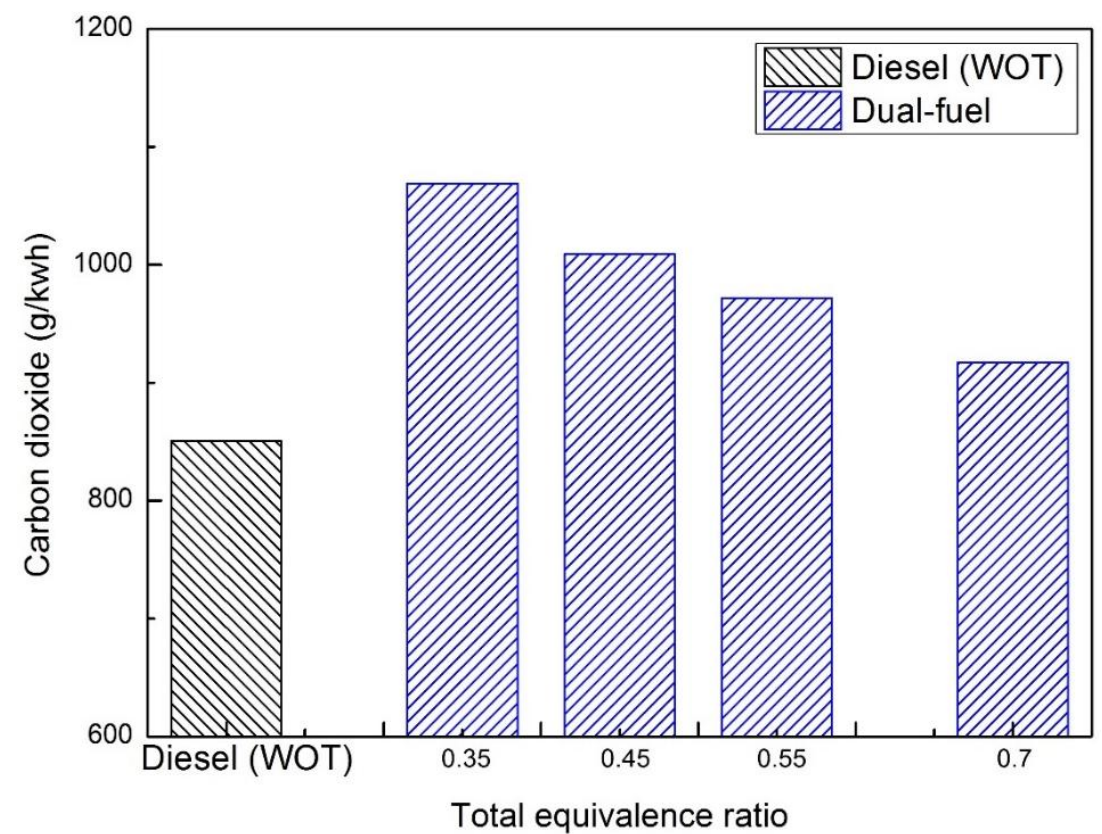

Fig.12. Variation in $\mathrm{CO}_{2}$ emissions with different $\phi$.

\section{Conclusion}

In the present work, an experimental investigation was conducted to study the effects of equivalence ratio $(\phi)$ variations on the combustion characteristics, performance and exhaust emissions of a dual fuel (DF) diesel engine operating on biogas fuel at high load ( $80 \%$ of full load). The experiments were performed with a fixed energy input to the engine while the percentage energy substitution (PES) was kept constant (60\%). $\phi$ was varied from 0.35 to 0.7 . The results led to the following conclusions:

- The peak of in-cylinder pressure under DF mode was lower than that observed for conventional mode for all the cases studied. Also, the peak of in-cylinder pressure decreased as $\phi$ increases for DF operation.

358 - Under DF mode, as $\phi$ increases, the ignition delay became longer and the heat release rate gave higher peak for the premixed phase.

- Concentrations of THC, $\mathrm{CO}, \mathrm{CO}_{2}$ and $\mathrm{NOx}$ were reduced with about $77 \%, 58 \%, 14 \%$ and

$36124 \%$ respectively when $\phi$ was varied from 0.35 to 0.7 .

- The BTE was improves by about $13 \%$ with increasing $\phi$ under DF mode. Moreover, at $\phi=0.7$, the BTE is higher than that of conventional mode by about $19 \%$. 
The authors are very thankful to all the technicians in the laboratory of Ecole des Mines de Nantes for their help and for kind collaboration in this study.

\section{$\underline{\text { References }}$}

[1] Rasi S, Läntelä J, Rintala J. Trace compounds affecting biogas energy utilization a review. Energy Convers Manage 2011;52:3369-75.

[2] Demirbas A. Biofuels sources, biofuel policy, biofuel economy and global biofuel projections. Energy Convers Manage 2008;49:2106-16.

[3] Frijns J, Hofman J, Nederlof M. The potential of (waste) water as energy carrier.Energy Convers Manage 2013;65:357-63.

[4] Elsayed M, Andres Y, Blel W, Gad A, Ahmed A. Effect of VS organic loads and buckwheat husk on methane production by anaerobic co-digestion of primary sludge and wheat straw. Energy Convers Manage 2016;117: 538-547.

[5] Lounici M S. Contribution à la réduction de la pollution urbaine en Algérie par recours à l'utilisation de carburants alternatifs, PhD Thesis, 2011, Université de Boumerdes (in french).

[6] Abhishek P, Sekhar P R, Durbadal D, Kumar B P. Effect of compressed natural gas dual fuel operation with diesel and Pongamia pinnata methyl ester (PPME) as pilot fuels on performance and emission characteristics of a CI (compression ignition) engine. Energy 2014; 68:495-509.

[7] Ryu K, Effects of pilot injection pressure on the combustion and emissions characteristics in a diesel engine using biodiesel-CNG dual fuel. Energy Convers Manage 2013;76(0):506516.

[8] Van Mitzlaff K. Engines for biogas. Deutsches Zentrum fur Entwicklungstecknologien, 1988, ISBN 35-2802-0326.

[9] Bora Bhaskor J, Saha Ujjwal K, Chatterjee S, Veer V. Effect of compression ratio on performance, combustion and emission characteristics of a dual fuel diesel engine run on raw biogas. Energy Convers Manage 2014;87:1000-1009.

[10] Barik D, Murugan S. Investigation on combustion performance and emission characteristics of a DI (direct injection) diesel engine fueled with biogas-diesel in dual fuel mode. Energy 2014;72:760-71.

[11] Barik D, Murugan S. Experimental investigation on the behavior of a DI diesel engine fueled with raw biogas-diesel dual fuel at different injection timing. J Energy Inst 2015. 
[12] Bari S. Effect of carbon dioxide on the performance of biogas/diesel dual-fuel engine. Renew Energy 1996;9:1007-10.

[13] Bedoya ID, Saxena S, Cadavid FJ, Dibble RJ. Exploring strategies for reducing high intake temperature requirements and allowing optimal operational conditions in a biogas fueled HCCI Engine for power generation. ASME J Eng Gas Turb Power 2012;134:1-9.

[14] Sahoo BB. Clean development mechanism potential of compression ignition diesel engines using gaseous fuels in dual fuel mode. Ph.D. thesis. India: Centre for Energy, IIT Guwahati 2011.

[15] Kyunghyun R. Effects of pilot injection timing on the combustion and emissions characteristics in a diesel engine using biodiesel-CNG dual fuel. Appl Energy 2013;111:72130 .

[16] Barik D, Murugan S. Simultaneous reduction of NOx and smoke in a dual fuel DI diesel engine. Energy Convers Manage 2014;84:217-26.

[17] Abhishek P, Sekhar P R, Durbadal D, Kumar B P. Effect of compressed natural gas dual fuel operation with diesel and Pongamia pinnata methyl ester (PPME) as pilot fuels on performance and emission characteristics of a CI (compression ignition) engine. Energy 2014;68:495-509.

[18] Xiangang W, Cheung CS, Yage D, Zuohua H. Diesel engine gaseous and particle emissions fueled with diesel-oxygenate blends. Fuel 2012;94:317-23.

[19] Karim G A. A review of combustion processes in the dual fuel engine - the gas diesel engine. Progr Energy Combust Sci 1980;6:277-85.

[20] Carlucci A A P, de Risi A, Laforgia D, Naccarato F. Experimental investigation and combustion analysis of a direct injection dual-fuel diesel-natural gas engine. Energy 2008; $33: 256-263$.

[21] Sayin C, Canaksi M. Effects of injection timing on the engine performance and exhaust emissions of a dual-fuel diesel engine. Energy Convers Manage 2009;50:203-13.

[22] Papagiannakis RG. Study of air inlet preheating and EGR impacts for improving the operation of compression ignition engine running under dual fuel mode. Energy Convers Manage 2013;68:40-53.

[23] Makareviciene V, Sendzikiene E, Pukalskas S, Rimkusb A, Vegneris R. Performance and emission characteristics of biogas used in diesel engine operation. Energy Convers Manage 2013;75:224-33.

[24] Srinivasan K K, Krishnan S R, Qi Y. Cyclic combustion variations in dual fuel partially premixed pilot-ignited natural gas engines. J. Energy Resour. Technol 2014;136(1).

[25] Lounici M, Loubar K, Tarabet L, Balistrou M, Niculescu D.C, Tazerout M. Towards improvement of naturel gas-diesel dual-fuel mode: an experimental investigation on performance and exhaust emissions. Energy 2014;64:200-211. 
[26] Abdelaal M M, Hegab A H. Combustion and emission characteristics of a natural gasfueled diesel enginewith EGR. Energy Convers Manage 2012; 64 (0):301-312.

[27] Henham A, Makkar M K. Combustion of simulated biogas in a dual fuel diesel engine. Energy Convers Mange 1998;39: 2001-9.

[28] Awad S, Loubar K, Tazerout M. Experimental investigation on the combustion, performance and pollutant emissions of biodiesel from animal fat residues on a direct injection diesel engine. Energy 2014;69:826-36.

[29] Khiari K, Awad S, Loubar K, Tarabet L, Tazerout M. Experimental investigation of pistacia lentiscus biodiesel as a fuel for direct injection diesel engine. Energy Convers Manage 2016;108:392-399.

[30] Tarabet L, Loubar K, Tazerout M. Experimental investigation of DI diesel engine operation with eucalyptus biodiesel/naturel gas under dual-fuel mode. Fuel 133 (2014) 129138.

[31] Kezrane C, Awad S, Loubar K, Liazid A, Tazerout M. Experimental assessment of performance and emissions maps for biodiesel fueled compression ignition engine. Appl Energy 2016;161:320-329.

[32] Luijten C C M, Kerkhof E. Jatropha oil and biogas in a dual fuel CI engine for rural electrification. Energy Convers Manage 2011;52(2):1426-38.

[33] Barik D, Murugan S. Investigation on performance and exhaust emissions characteristics of a DI diesel engine fueled with Karanja methyl ester and biogas in dual fuel mode. In: SAE Technical Paper 2014-01-1311; 2014.

[34] Papagiannakis R G, Rakopoulos C D, Hountalas D T, Rakopoulos D C. Emission characteristics of high speed, dual fuel, compression ignition engine operating in a wide range of natural gas/diesel fuel proportions, Fuel 2010; 89 (7):1397-1406.

[35] Daouk E, Loubar K, Lounici M S, Tazerout M, Experimental investigation and combustion analysis of biogas with different compositions in dual fuel diesel engine, IREC 2012, Sousse, Tunisia, 20-22 December 2012.

[36] Wannatong K, Akarapanyavit N, Siengsanorh S, Chanchaona S, Combustion and knock characteristics of natural gas diesel dual fuel engine, SAE Technical Paper 2007-01-2047, 2007.

[37] Papagiannakis R G, Hountalas D T.Combustion and exhaust emission characteristics of a dual fuel compression ignition engine operated with pilot diesel fuel and natural gas. Energy Convers Manage 2004; 45 (18-19):2971-2987.

[38] Liu J, Yang F, Wang H W, Ouyang M G, Hao S G. Effects of pilot fuel quantity on the emissions characteristics of a CNG/diesel dual fuel engine with optimized pilot injection timing. Appl. Energy 2013; 110 (0):201-206. 
[39] Imran S, Emberson D R, Diez A, Wen D S, Crookes R J, Korakianitis T, Natural gas fueled compression ignition engine performance and emissions maps with diesel and RME pilot fuels. Appl Energy 2014; 124:354-365.

[40] Sun L, Liu YF, Zeng K. Combustion performance and stability in dual fuel engine with different pilot diesel injection timing. J Xi' an Jiaotong Univ 2014; 48 (7): 29-33

[41] Zhou L, Liu YF, Sun L, Hou HX, Zeng K, Huang ZH. Effect of hot exhaust gas recirculation on the combustion characteristics and particles emissions of a pilot-ignited natural gas engine. Society of Automotive Engineers (SAE) technical paper 2013; 01-1341.

[42] Liu J, Yang F, Wang H, Ouyang MG, Hao SG. Effects of pilot fuel quantity on the emissions characteristics of a CNG/diesel dual fuel engine with optimized pilot injection timing. Appl Energy, 110 (2013), pp. 201-206

[43] Internal combustion engine fundamentals, John B. Heywood. McGraw-Hill Book Co. New York, 1988, ISBN: 978-0071004992.

[44] Wei L, Geng P. A review on natural gas/diesel dual fuel combustion, emissions and performance. Fuel Process Technol 2016 ; 142: 264-278.

[45] Debabrata B, Murugan S. Effects of diethyl ether (DEE) injection on combustion performance and emission characteristics of Karanja methyl ester (KME)-biogas fueled dual fuel diesel engine. Fuel 2016; 164: 286-296. 